\title{
Motives for consideration of CSR concept assumptions for building a business strategy
}

DOI: http://dx.doi.org/10.12775/JCRL.2014.001

\author{
Marta Ceglińska ${ }^{\mathrm{a}}$, PaweŁ Cegliński ${ }^{\mathrm{b}}$ \\ ${ }^{\mathrm{a}}$ The Faculty of Economic Sciences and Management, \\ Nicolaus Copernicus University, Toruń, Poland \\ $\mathrm{b}$ The Faculty of Economic Sciences and Management, \\ Nicolaus Copernicus University, Toruń, Poland \\ e-mail: pawelceglinski@gmail.com
}

\begin{abstract}
This paper constitutes an attempt of synthetic description of changes in the approach to the process of building a business strategy, which have been established recently and still increase. They are connected, to a great extent, with the dynamically developing concept of corporate social responsibility. Numerous academic papers have been written on the subject. However, the problem of conduct of businesses in compliance with principles of the concept of corporate social responsibility is disputable, both in the sphere of doctrine and economic practice.
\end{abstract}

Keywords: business strategy, business stakeholders, competitive advantage, environmental protection, brand, consumer behaviour.

\section{Introduction}

This paper touches upon the problem of changes in the approach to building a business strategy, which have occurred recently. The changes have occurred, above all, owing to the dynamically developing concept of corporate social responsibility. Presently, in connection with the very 
instable economic situation, entrepreneurs search for a business model, which would be profitable for a long period of time and, at the same time, allow for reduction of the widely understood risk. It seems that assumptions of corporate social responsibility are not able to ensure permanent advantages for business owners. It does not have to be explained that any long-term activities should be conducted on the basis of a properly formalized strategy. It is undoubtedly a condicio sine qua non for effectiveness of the same.

The authors start their deliberations with presenting theoretical issues, which form the basis for their further more detailed deliberations relating to business strategies and significant motives for building the strategy as based on assumptions of corporate social responsibility.

\section{Aims of functions of a business organisation and approach to $\mathrm{CSR}$ concept}

The use of the concept of corporate social responsibility in practice is closely connected with theories relating to the main aim of functions of a business organisation. The existence of each enterprise is based on a determined business concept. It is composed of three elements. Firstly, there is a function, which an entity wants to fulfil in the market. Secondly, there is a method for fulfilment of the function, which should be understood widely inclusive of customer service. Thirdly, there is a segment of the market, which specifies the area of activities of an enterprise (Białasiewicz and Marek, 2008, p. 33). In simple terms, it may be referred to an answer to a simple question asking, why a given business organisation conducts its activities and how it does it.

Generally or, at least, since the 1980s, it has been assumed that the main aim of an enterprise is to create its shareholder value. It is the so-called theory of increasing enterprise value. It also constitutes a decisive criterion of evaluation of various strategies of an enterprise (Rappaport, 1995, pp. 1-15). The basic assumption of the concept involves such structuring and running of an enterprise so that its shareholder value could be maximised (Białasiewicz and Marek, 2008, p. 41).

Now, the first approach to the concept of CSR is beginning to clarify and it is a critical approach. Friedmann, a prominent economist and the Noble prize winner is its leading representative. In his opinion, business has only one social responsibility, namely it can use its resource and use 
the same for activities in order to increase profits as long as it complies with rules. This means that it participates in open and free competition without any tricks and deceit (Friedmann, 1963). On the other hand, Sternberg claims that the only responsibility of an enterprise is to act for the sake of its owners, and considering the good of stakeholders is a wrong economic theory (Sternberg, 1998, p. 68). Without downgrading theories of the prominent economists, it has to be stated that the presented views are connected more with a doctrinal and ideological approach than with a practical approach to the problem of corporate social responsibility. Friedmann and his followers, similar to Hayek or Lippmann propagate values constituting the stem of a doctrine of neoliberalism. It refers directly to the canons of classical $19^{\text {th }}$-century liberalism. Justyński indicates that the doctrine is based upon freedom including a sphere of political freedoms, freedom of competition and freedom of economic activities. Emphasizing freedom in the sphere of politics and economics, neoliberalists also act as opponents of the notion of social rights, thus rejecting egalitarianism and interference with social and economic processes through planning (Justyński, 2009, p. 489).

Therefore, it seems that it is justified to claim that the doctrine of liberalism has exerted a significant influence upon views of the indicated representatives of science on the concept of corporate social responsibility. In this context, one should bear in mind that political, social or economic views of given groups, including even those very comprehensibly educated ones, are not often reflected in reality. They are always validated by the market and, recently, the validation has been particularly merciless. However, it is the market that, according to liberalists, should dictate conditions of economic activities.

In order not to be biased, one should note that to perceive a business organisation in a way that such representatives of science as Handy did, is perhaps even more controversial than the previous approach. The author rejects perceiving a company as a property deeming such perception a leftover from the $19^{\text {th }}$ century. In his opinion, a company is a social unit, which means that it should act within the network of its relations and interdependencies. Following this line of reasoning, Handy states that in the $21^{\text {st }}$ century stockholders invest in an enterprise and are not, in any sense, its owners, whereas recognition of profits as an aim of a company's existence is a tragic error (Handy, 2002, pp. 133-143). The rejection of ownership rights implies the undermining 
of foundations of the economic system, basic rights of an individual and guaranteed protection of the rights by the state. In the Polish legal system, this can be reflected, among others, in Article 64 of the Constitution of the Republic of Poland, which guarantees the right of ownership and protection of the same. However, Handy seems to forget about a basic issue. The concept of corporate social responsibility is not an aim in itself. It constitutes means to an aim and something that supports a company on a long-term basis and cannot, in any way, substitute the aim. With this approach, one is only a step away from treating business organisations as obliged to participate in common charitable activities and, perhaps, even from socialist views.

Going back to the concept of creating the shareholder value, from the business point of view, it should seem most obvious and comprehensible. However, it is too general and it focuses, above all, on generation of profits, disregarding interests of groups other than stockholders. Sudoł emphasizes that a lot of parties and not only owners are interested in the success of an enterprise in attainment of its aims. These include, among others, managers, employees, a lot of institutions and persons closely connected with an enterprise, including customers, suppliers, co-operators, creditors, banks and local community. All these individuals and institutions are referred to as stakeholders (Sudoł, 2006, p. 72). Therefore, they more and more often say about the need to balance interests of all stakeholders, which are often contrary to one another (Sudoł, 2006, p. 72).

Grant mentions as many as 13 groups of stakeholders. All of them experience effects of activities of an organisation and are interested in results of its activities. The groups include customers, local community, suppliers, employees, groups of interest, commercial associations, owners/investors, courts, schools and universities, governments of other countries, the government of one's own country, local authorities and creditors (Grant, 2011, p. 81).

In the opinion of the authors of this paper, the concept of corporate social responsibility should be treated from the point of view of advantages, which it can bring both to an enterprise and society. It seems that such an approach is, to the fullest extent, presented by Porter and Kramer. They propagate a pragmatic approach to the problem of corporate social responsibility. They treat the concept as a practical tool used for creation of a company's positive image and strong brand. For them, CSR is one of instruments, which a company can use for building 
permanent competitive advantage. The authors also postulate that activities undertaken as part of the concept, should be an internal part of a company's general strategy. Consequently, it is not difficult to see that Porter and Kramer suggest adopting an assumption that activities for society should bring value for a company. However, any activities constituting a response of an organisation to hazards, including, but not limited to, deeming the activities inadmissible, do not fulfil conditions of a pragmatic approach to the concept of CSR (Kramer and Porter, 2007). The above-mentioned approach seems to comply with the spirit of "true" corporate social responsibility. Moreover, it indicates marginal significance of sporadic charity campaigns or philanthropic activities done for show. If a company decides to put the concept of CSR into practice, it should do it properly and leave „money giving” to charity organisations.

\section{Basic assumptions of corporate strategy}

A basic task of the strategy is to accomplish specific aims of an organisation. The authors consider the previously presented Porter and Kramer's pragmatic concept as the most appropriate approach to CSR and company's aims and this approach will be applied when discussing the issue of the strategy and its relation to corporate social responsibility.

The strategy may be described as a comprehensive plan of accomplishment of aims of an organisation (Griffin, 2004, p. 245). It may also be understood as means used by individuals and organisations for accomplishment of their own aims (Grant, 2011, p. 31). Grant indicates that a common element of most definitions of the strategy is an opinion that it focuses upon accomplishment of some aims, that most important activities, which make up the strategy, are connected with allocation of resources and that the strategy means a certain consequence, integration and coherence of decisions and activities (Grant, 2011, p. 31).

In a classical approach, the strategy is made of two basic levels, namely a corporate and business strategy. Decisions made as part of the first type of aforementioned strategies include choices relating to diversification, vertical integration, take-overs and new undertakings and allocation of resources among various fields of activities. On the other hand, the business strategy deals with a way, in which a company competes in a given sector or market. 
The concept of corporate social responsibility should be reflected in a business strategy, i.e. the way, in which a company competes. Therefore, a company, which is to act in accordance with its assumptions, should plan CSR like any other field of its activities. Going back to Porter and Kramer's pragmatic approach, sporadic and chaotic activities do not belong to the concept of corporate social responsibility.

Figure 1. Sources of extraordinary profitability

Source: Grant, 2011, p. 34.

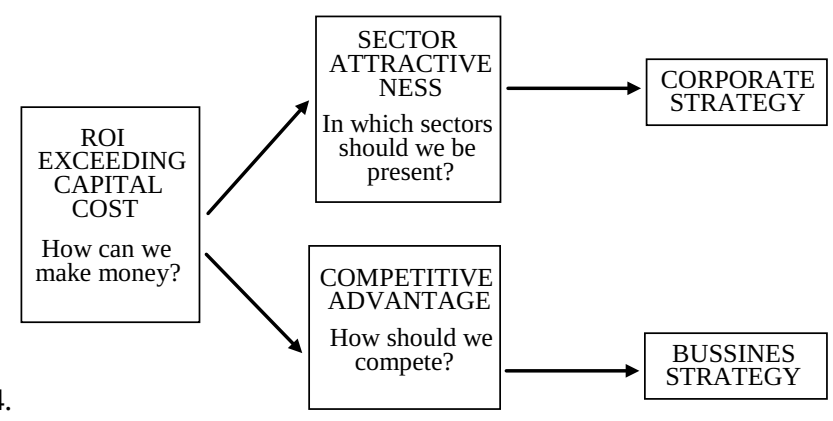

Bearing in mind that an enterprise is not a charity organisation, one should ask, whether implementation and realisation of assumptions of corporate social responsibility is advantageous for a company. It can be doubtful, if we think about a short period of time. However, in the long run, CSR may become a reliable factor of competitive advantage.

Bernacka and Jędrzejowska (2012, p. 118) mention the following advantages of implementation of the concept of CSR in an enterprise:

1. Economic advantages:

- building a positive image of an organisation in the market;

- attracting new customers;

- increase in confidence of the present customers;

- increase in effectiveness of conducted economic activities;

- competitiveness in the market;

- increase in the investor interest;

- possible deduction of donations for social purposes from the tax basis;

2. Managerial advantages:

- an organisation as an attractive employer;

- good information flow and communication within an organisation; 
- greater motivation and commitment of employees;

- involving employees in the process of management;

- better organisational culture;

3. social advantages:

- publicising of the issue of corporate social responsibility;

- stimulation of economic development in a city and contribution to the growth of prosperity of its inhabitants;

- education of society;

- influence upon improvement of natural environment;

- creation of charitable attitudes.

Further, this paper presents some of prerequisites for consideration of concepts of CSR in the process of creation of a company's business strategy. They are closely connected with the above-mentioned advantages. Due to the limited length of this paper, the authors decided to limit to aspects, which, from the point of view of economic activities and according to the authors, have recently become most significant.

\section{The brand and confidence in a company}

Undoubtedly, there is an urgent need to restore social confidence in large companies. The only way to do this is to discern and accept fears expressed in companies and wider circles of stakeholders associated with the company (Floyd et al., 2011, pp. 303-304). The above-mentioned thesis, which was formulated at the end of the last world economic crisis, is still true. It should be remembered that brands are "companies' showcases". It seems that, following events of the last crisis, customers have changed their attitudes to companies considerably. The present tools for creation of a brand strength are still important, but not sufficient. A new social dimension of a brand is playing a more and more important role.

Niziński points out that after the epoch of acquisitive consumption, which dominated in the 1990s and a part of the last decade, fundamental revaluation of some consumers' attitudes can be observed. This phenomenon can be observed, above all, in western societies, however, some trends are also visible in Poland. In the authors' opinions, it is not diversification, innovativeness, clear vision, good contact with consumers or abstractive price positioning that determine the value 
of a brand. What is becoming more and more significant is whether companies behind brands adhere to ethics, keep their promises or take care of natural environment and their products are useful for the society (Niziński, 2011).

It seems that fears connected with the crisis caused a visible return to values such as a home, family, stability, internal harmony, thriftiness or contact with nature (Niziński, 2011). Perhaps, these values relate subconsciously to a desire to prevent similar events in the future. It should be remembered that one of causes of the crisis was excessive consumption connected with debts and living beyond one's means, which is often done for show. Its quality is the same.

An interesting example of the change in approach to a brand has recently been a "no logo" trend propagated on a great scale by Naomi Klein as based on her book with the title of "No logo", which has been a bestseller. It should be emphasized that this does not mean a loss of significance of a brand as such. It still fulfils its basic tasks such as enabling market segmentation to a manufacturer or simplification of the process of decision-making to a customer when buying and guaranteeing that a product of a given brand will always be of the same quality. However, it seems that a considerable change can be observed in the sphere of so-called symbolic function of a brand, which results from social dimension of consumption (Kall, 2001, pp. 12-15).

\section{Consumer behaviours}

Synthetically speaking, consumption is defined as an act or process of satisfaction of human needs with then use of goods and services (Janoś-Kresło and Mróz, 2006, p. 61). It is doubtless that, a human being first aims at satisfying his/her most fundamental needs. For example, Maslow refers to the same as physiological needs (Griffin, 2004, pp. 521-523).

With the growth of satisfaction of his/her fundamental needs, a human being aims at satisfying his/her higher needs. Basically, a degree of satisfaction of human needs complies with the level of development of society as a whole. One does not have to make deep economic inquiries in the subject in order to see the relationship. At first glance, inhabitants of so-called third world countries will have different 
needs than inhabitants of most developed European countries. Thus, it is not surprising that the concept of corporate social responsibility evolves in the latter.

The contemporary consumption and consumer behaviour are also based upon, and even above all, ethical prerequisites. Economic factors manifesting, above all, in prices of goods and services purchased, have somewhat lost their significance. Obviously, as it has already been mentioned, it depends, to a great extent, on a degree of development of a given society. In this context there appears a concept of so-called ethical consumption. This concept is understood widely. Speaking about ethics in consumption, one should mean mainly consumer behaviour oriented toward acquisition and use of products in accordance with fundamental principles of contemporary ethics (Smyczek, 2012, p. 162; Velasquez, 2006).

Such behaviour is reflected, among others, in:

- resignation from consumption of goods, which are obtained as a result of killing of animals,

- resignation from goods, which have been manufactured with the use of slavery, work for non-equivalent remuneration, work of children etc.,

- responding to unethical behaviour of enterprises,

- resignation from gadget consumption etc. (Bywalec, 2007, p. 139).

Consumers in highly developed societies manifest their ecological awareness more and more often, which results in growing interest in eco-consumption and eco-industry. They become more and more sensitive to damage made to the environment in the process of use of products. They are aware that their activities can generate external side effects not only on a local scale, but on a global scale as well, as one of effects of mass consumption involves large quantities of post-consumption waste, which are as much harmful as post-production waste (Bywalec, 2007, p. 138; Woś et al., 2011, p. 163).

Consumers do not resign from their current habits connected with purchase of goods, but correct the same accordingly. They resign from products sold in plastic packaging and choose glass or paper packaging and participate actively in waste sorting, which allows for recycling of the same. If consumers decide to get rid of a product, they may, if they have appropriate knowledge, consider wellbeing of the environment (Woś et al., 2011, p. 164). 
The literature distinguishes between external and internal factors motivating for getting rid of products as shown in the below table.

Table 1. Factors motivating for getting rid of products

\begin{tabular}{ll}
\hline External motivation & Internal motivation \\
\hline - taxes, fees & - ecological knowledge \\
- ecological campaigns & - care of the environment \\
- proximity of recyclable waste bins & - time preference \\
- frequency of waste removal & - social influences \\
\hline
\end{tabular}

Source: Antonides and Raaij, 2003, p. 520.

Social influence is another very significant issue, which determines consumer behaviour. Departing from the general approach and proceeding to consumption in Poland, one should note that the Poles aim at consumption patterns typical of developed Western countries (Sikorska, 1998, p. 103).

They say about a growing effect of consumption for show. Simply speaking, the consumption comes down to snobbism and purchasing goods, which a consumer could not afford without a credit or loan. Paradoxically, it may be rather controversial, but it can be assumed that socially responsible products are also a form of consumption for show. Obviously, a significant factor is the very ecological awareness. However, in Poland, ecological products with Fair Trade marks etc. are disproportionately expensive as compared to analogical goods, which do not have much in common with CSR. The degree of association of purchase of CSR products with internal awareness of a customer or with a trend for such products will not be discussed in detail in this paper for objective reasons.

\section{Legal issues}

At the beginning of this paper it is emphasized that realisation of the concept of corporate social responsibility should be connected with voluntary activities. It is true, however, a series of socially responsible behaviours are forced by legal regulations and a failure to adhere to legal standards results in sanctions. A motive for implementation of the 
sanctions is, above all, undisputable degradation of the natural environment accompanied by industrial development and associated strong pressure exerted upon employers by the society.

The literature emphasizes that in order to put corporate social responsibility in practice in a business model, it is necessary to adjust all procedures and guidelines, which make enterprises consider requirements of all affected parties and reflect upon activities conducted. Most important procedures and guidelines include:

- OECD guidelines for multinational enterprises,

- principles of conducting of business activities adopted during round table talks in Caux,

- the initiative of "Global Compact",

- AA1000 and SA8000 (Bernacka and Jędrzejowska, 2012, p. 106) standards and many others and, in particular, numerous regulations and directives of the European Union, to which Poland has to adjust its legal system.

Significance of the problem is proved by the number of legal provisions relating to environmental protection in Poland. The doctrine points out to numerous general principles of the law. From the point of view of business, most important may include the principle of sustainable development, prevention, precaution principle and the polluter-pays principle. It is worth emphasizing that the first of the above-mentioned principles is stated directly in Article 5 of the Constitution of the Republic of Poland.

\section{Conclusions}

Concluding, the concept of corporate social responsibility is not a philanthropic activity or simple money giving as some may deem. It does not negate, in any way, the basic task of entities conducting business activities, i.e. increasing the shareholder value, which implies growth of profits. On the contrary, application of the concept of CSR will increase profitability of business activities in the long run. Indisputably, its basis results in increase of confidence of the present consumers and attracts new consumers, which allows for hiring and maintaining of valuable employees even in the moments of crisis. What is more, it can be stated with full conviction that implementation of the concept is in compliance with fundamental principles of activities of an enterprise. 
The concept of corporate social responsibility is now becoming a basis of modern business strategies, which help an enterprise to adjust to the turbulent environment, which is changing even quicker, and achieve permanent competitive advantage.

\section{Bibliography}

Antonides, G., van Raaij, W.F. (2003), Zachowanie konsumenta: Podręcznik akademicki, PWN, Warszawa.

Bernacka, M., Jędrzejowska, U. (2012), “Społeczna odpowiedzialność biznesu w budowie wartości przedsiębiorstwa”, in: Jabłoński, A. (Ed.), Strategiczny wymiar funkcjonowania współczesnych organizacji: Strategie, modele biznesu, finanse, zasoby ludzkie, relacje, Wyższa Szkoła Biznesu w Dąbrowie Górniczej, Dąbrowa Górnicza.

Białasiewicz, M., Marek, S. (2008), Podstawy nauki o organizacji, PWE, Warszawa.

Bywalec, C. (2007), Konsumpcja w teorii i praktyce gospodarowania, PWN, Warszawa.

Floyd, S.W., Sherman, H.D., Sigismund Huff, A., Terjesen, S. (2011), Zarzqdzanie strategiczne: Podejście zasobowe, Wolters Kluwer, Warszawa.

Friedmann, M. (1963), Capitalism and Freedom, University of Chicago Press, Chicago.

Grant, R.M. (2011), Współczesna analiza strategii, Oficyna a Wolters Kluwer business, Warszawa.

Griffin, R.W. (2004), Podstawy zarzqdzania organizacjami, PWN, Warszawa.

Handy, C. (2002), “What’s a Business For?”, Harvard Business Review, December.

Janoś-Kresło, M., Mróz, B. (2006), Konsument i konsumpcja we współczesnej gospodarce, Wydawnictwo SGH, Warszawa.

Justyński, J. (2009), Historia doktryn polityczno-prawnych, Dom Organizatora, Toruń. Kall, J. (2001), Silna marka: Istota i kreowanie, PWE, Warszawa.

Kramer, M.R., Porter, M.E. (2007), “Strategia a społeczeństwo: społeczna odpowiedzialność biznesu - pożyteczna moda czy nowy element strategii konkurencyjnej?”, Harvard Business Review Polska, czerwiec,

Niziński, P. (2011), “Społeczny wymiar: nowy atut marki”, Harvard Business Review Polska, marzec.

Rappaport, A. (1995), Shareholder Value - Wertsteingerung als Massstab für die Unternehmensführung, Schäffer-Poeschel Verlag, Stuttgart.

Sikorska, J. (1998), Konsumpcja: Warunki, zróżnicowania, strategie, IFIS PAN, Warszawa.

Smyczek, S. (2012), Nowe trendy w zachowaniach konsumentów na rynkach finansowych, Placet, Warszawa.

Sternberg, E. (1998), Czysty biznes: Etyka biznesu w działaniu, Wydawnictwo Naukowe PWN, Warszawa.

Sudoł, S. (2006), Przedsiębiorstwo, PWE, Warszawa.

Velasquez, M.G. (2006), Business Ethics: Concepts and Cases, Pearson Higher Education, London.

Woś, J., Rachocka, J., Kasperek-Hoppe, M. (2011), Zachowania konsumentów - teoria i praktyka, Wydawnictwo Uniwersytetu Ekonomicznego w Poznaniu, Poznań. 